\title{
Ideological Struggles and Identity Construction within the Politics of French Linguistics in Indonesia
}

\author{
Merry Andriani'; Wening Udasmoro'; Suhandano² \\ ${ }^{1}$ Student at the Department of Humanities Sciences, Universitas Gadjah Mada, Indonesia; \\ ${ }^{2}$ Department of Language and Literature, Universitas Gadjah Mada, Indonesia \\ Corresponding Email: merry.andriani@mail.ugm.ac.id
}

\begin{abstract}
This article aims to analyse the ideological struggles reflected in the identity construction of French-language users in Indonesia. Using a critical sociolinguistic approach, it examines how Indonesians users, with their ideologies, adapt or adopt the French language and culture, as well as the different patterns and models they use to do so. The informants of this research consist of 9 students in deep interviews, 60 students in class observation, and 15 lecturers at 12 Indonesian universities who have taught the French language and culture for at least two years. Data from the interviews is compared to French instruction books and media discourses using intertextuality and interdiscursivity analysis. This research identifies three models used by French users in Indonesia: to adopt French language and culture, to adapt it, or to abstain from the reproduction of both. Users of the first model completely adopt all aspects of French culture, including in their consumption and style. Meanwhile, users of the second model tend to select and accept only those aspects considered positive within their own value system. Those using the final model tend to ignore many aspects of French culture and language.
\end{abstract}

Keywords: French in Indonesia; identity; ideology; language politics; sociolinguistics

\section{INTRODUCTION}

The politics of linguistics is a relatively new domain in linguistic and sociolinguistic studies. Initially, most research and theories used the term "language planning", before shifting to "language policy". This article will apply the term "language politics" rather than "language planning", which implies a designing phase at the macro level, or "language policy", which strongly emphasises the role of the nation state in the production of law. "Language politics", meanwhile, recognises the power influences in social interactions (at both the meso and micro level) that influence how people use languages.

*) This article is part of a chapter in an ongoing dissertation intended to attain a doctoral degree at the Department of Humanities, Faculty of Cultural Sciences, Gadjah Mada University, Indonesia.
For example, in education institutions, as social spaces (thereby implying specific policymaking and strategies), the power who dominates the education regime will decide which language should be taught and how it should be taught. Another example is the use of language within Javanese families, which is mostly decide by parents or other family elders.

The term "politics" implies not only state and methodical aspects, but also formal power and legal aspects concerning language. Accordingly, the definition of Spolsky and Shohamy is compatible with this perspective. Spolsky and Shohamy define language politics as efforts to claim the authority to change others' language practices or ideology (Spolsky and Shohamy, $2000: 1)$. France is a primary example of a nation using language politics through policy. Their law concerning 
the use of French language can be traced back to 1539 (Article 111 of the ordonnance de Villers-Cotterêt, which required that French be used in court), and continued through a 1794 decree requiring that French be used as the language of instruction in all schools, was reaffirmed in a ministerial decree in 1881, continued in a 1975 law, and 1992 constitutional amendment. Most popularly, this requirement was legislated through the 1994 Loi de Toubon, which required the use of French in all consumer products, advertising, television programmes, films, education activities, audio-visual communications, and international scientific congresses held in France (Ager 1996, in Spolsky \& Shohamy, 2000, p. 3). The national language policy of France has played an important role in nation building.

On the international stage, French was a major lingua franca in Europe in the seventeenth and eighteenth centuries, as well as a main language of instruction at European schools (Wright, 2016). The dominance of French was strongly linked to the power of the contemporary French monarchy and military. The international use of French was also related to the country's prominence in science, technology, finance, culture, art, and politics, particularly its recognition as a political innovator. As Wright notes, France had a prominent role in the American Revolution, and Benjamin Franklin was a fluent speaker of French. At the same period, Indonesian history also notes the presence of French in eighteenth-century Batavia during the Dutch occupation. As indicate by Dorléans, many European countries at that time, including the Netherlands, were occupied by the French during the reign of Napoleon Bonaparte, who designated Herman Willem Daendels the Governor General of the Netherlands East Indies (Dorléans, 2006). Research by Cholsy shows also that, during this period of French rule the Dutch colonial forces in Java made several lexical contributions to the Indonesian language through French loan words (Cholsy, 2014, p. 305).

The decline of French as a lingua franca began as English began to dominate global culture through the spread of American culture. Conversely, French speakers also started promoting linguistic diversity by speaking different languages. Multilingualism emerged in France as linguistic diversity emerged, particularly through immigration. Although Wright argues that this strategy benefited the diffusion of the French language (Wright, 2016, p. 139), others have made entirely different arguments. One French linguist, Jean-Claude Beacco, explains that the French language and francophonie in general has had difficulty escaping the shadows of colonialism (Beacco, 2016). France has conceived several policies, involving various aspects of life, to collaborate with francophone countries (i.e. former French colonies), as reported by Jacques Attali to the President François Holland (Attali, 2014).

Presently, power and dominance are only rarely exercised through physical force such as colonisation. Rather, as argued by Fairclough (1995, p. 219), "it is an age in which the production and reproduction of the social order depends upon practices and processes of a broadly cultural nature. Part of this development is an enhanced role for language in the exercise of power: it is mainly in discourse that consent is achieved, ideologies are transmitted, and practices, meanings, values, and identities are taught and learnt". The teaching of French as a foreign language conveys discursive practices that are embedded with ideologies, and educational institutions at different levels are the main authorised agents in this practice of linguistic politics. Language teaching is a process of language transmission, one mostly practiced with the authorisation of the dominant power through educational institutions. Language transmission is one of the three strategies identified in the linguistic politics, a concept identified together with status planning and corpus planning by Cooper (1989).

In Indonesia, French language is one of several foreign languages taught at different levels and in various educational institutions. While a limited number of international primary schools provide French as subject, the Indonesian Ministry of Education only begins to offer French as foreign language subject at the senior high school level; this is limited to one session (45 minutes) per week. At the tertiary education level, French is taught as a main subject or department at only twelve universities throughout Indonesia. In universities, two orientations are used in teaching French: to produce future teachers and to produce different types of cultural professionals.

To understand the practice of the politics of French linguistics in educational institutions in Indonesia, mainly at the university level, this research will need to question students. Most pedagogical perspectives position them as objects. For example, in the positivistic perspective, students are measured in their capability to absorb the language through an acquisition process. However, students are seen here as the primary subjects in language politics, especially in the transmission of languages. Their voices, as subjects, are also important to be heard and analysed to understand their struggle within language transmission.

This research uses a post-structural perspective and involves as its informants students from two universities 
as well as the French Institute, as main2 transmitters of the French language. As learners, all informants have studied the French language for at least two years and started to use it. According to their institutional programmes, at this point students should have not only incorporated the French language within their discursive practices, but also its culture and ideologies. This research examines the following questions: how do Indonesian users of French adapt or adopt the French language and culture? What different models do they use to adapt or adopt French language and culture?

Previous research on French in Indonesia has focused mostly on pedagogical aspects of French acquisition, including grammatical perspectives or interferences (Tobing 2012, Noworini 2003, Endi 2013). Many Indonesian scholars interested in French linguistic research have used as their research problem the metalinguistic and comparative grammatical differences between French and Indonesian and applied a structural approach (Baskoro 2000, Cholsy 2005, Rahayu 2012). They have tended to focus only on language issues, or on linguistic variations used by French-speaking society. Little attention has been given to French language use in an Indonesian context. This lack of contextual literature has been a major difficulty in this research. Fortunately, we can find abundant references and research for this perspective internationally, in domains such as language policy, language teaching and learning, identity, sociolinguistics, and critical discourse analysis.

Based on this situation, this research analyses the problems formulated above using a post-structural paradigm to examine the intersection of language politics, identity, and critical discourse analysis. The French language and culture, in the context of foreign language teaching, is considered a product of the linguistic market (Bourdieu, 1982). Accordingly, the French language and culture is put in a cycle of production/consumption/ reproduction within the discourse of language politics. One motivation for learning a new language is to gain social capital and thereby elevate one's social class. As said by one student during her interview, explaining why she chose to study French:

"Soalnya bahasa Inggris itu udah biasa banget, semua orang pasti bisa lah. Tapi kalau bisa bahasa Prancis itu lebih keren aja, beda dari orang kebanyakan. Jadi lebih chic gitu."

Translation: Speaking English is a very common thing. Everybody can do it. But if one can speak French, it is better. It's different than the common people. So, it is more chic.
Language always has many representations of imagined communities, to borrow Anderson's term in a linguistic context (Pavlenko and Norton 2007). To join the imagined community of language users, a learner must construct an imagined identity, enhanced by language acquisition (Norton, 2013). The construction of identity is a main challenge for students during their youth.

To borrow the definition of Hall (1996, pp. 5-6), identity is the meeting point between discourse and practice that attempts to place social subjects within particular discourses. He argues that identities are points of temporary attachment to subject positions constructed for us by discursive practices. This perspective is congruent with that promoted by post-structural views such as Bakhtin's, for whom identity is multi-voiced, never fixed or permanent. According to Bakhtin, this process happens in ideological environments where many discourses meet. It is "the ideological becoming of a human being, the process of selectively assimilating the words of others" (Bakhtin, 1981, p.341). For Bakhtin, the words of others play an important role in selfconstruction: "another's discourse performs here no longer as information, directions, rules, models, and so forth, but strives rather to determine the very basis of our ideological interrelations with the world, the very basis of our behaviour. It performs here as authoritative discourse, and an internally persuasive discourse" (1981, p. 342). Authoritative discourses include the hierarchic words of authority and religious dogma, also known as "father's word". It is in opposite to the internally persuasive discourse known as "one's own word". Furthermore, Bakhtin argues that, in discourse developments within ourselves, we can experiment, identify, and separate these two discourses and reject the one "that does not matter to us or does not touch us" (1981, p. 345). Within this research context, the process could be considered as a daily struggle for language learners or users during their French studies, as being confronted to diverse discourses and culture that are sometimes opposed ideologically to their authoritative voice. Using the Common European Framework paradigm, French language transmission emphasises the importance of introducing a language together with its sociocultural aspects. Therefore, students should acquire French values such as liberté or freedom in their ways of thinking, expressions, arts, fashions, relationships, religious practices, etc. Certain values are sometimes very new to them, but others are quite familiar, as they have already seen French films, listened to French music, or otherwise accessed French media through the internet.

In this article, we will discuss the ideological 
environment for French-language users in Indonesia. Understanding this environmental context is necessary to obtain a comprehensive view of the models used by Indonesians to adapt, adopt, or abstain from French language and culture. Second, considering the limitations of this article, we will elaborate only a particular part, not the whole problem. The focus is on aspects of language learners' identity struggles and constructions, as related to fashion identities, ideologies, and religious dogma. These three subjects are discussed in the French instruction books used at universities, and were the most frequently brought up by informants during interviews.

\section{FINDINGS AND DISCUSSION}

\section{Common European Framework: New paradigm in language transmission}

In the context of language politics and the learning of French as a foreign language in Indonesia, we found that French instruction books are presented together with methodologies imported directly from France. Today, most French instruction books for foreigners are produced using the Common European Framework (henceforth $\mathrm{CEF}$ ) for language. The product of an agreement between 39 European and non-European countries (Japan, Canada, United Arab Emirates, etc.), CEF requires the implementation of certain recommendations in language learning, teaching, and practice. Indonesia has used CEF in institutional programmes for higher education, without any preliminary study of this instrument of linguistic politics, since 2005 .

This research has found five primary aspects of CEF that completely modify didactic and linguistic practices. First, the diffusion of language must consider the importance of linguistic and cultural pluralism. Second, CEF recommends six different levels of language learning and teaching: A1, A2, B1, B2, C1, and C2, all of which come with auto-evaluation principals. These six levels not only measure linguistic competence, but also pragmatic and socio-cultural knowledge. Third, CEF recommends an action perspective in language teaching. Fourth, the optimal use of instruments, such information technology, is necessary to strengthen the methodology used in classroom. Fifth, to achieve language goals, language users are required to have competence in savoir (knowledge), savoir-faire (know-how), and savoir-être (know-how-to-be). This last aspect has the risk of (or opportunity to) influencing and changing language learners' identities. Most language users in university are between the ages of 18 and 20, emerging adults in a crucial phase for the construction of identity.

Instruction books are not the only knowledge resources used by French language users in class. They also use resources from the media and the internet, through which they have the chance to gain more knowledge and linguistic practices related to their language target. Indonesia has the highest number of internet users in Southeast Asia. Of its population of more than 200 million, $50.4 \%$ muses the internet, and $78 \%$ have at least one social media account (See Table 1 below)

These statistics show the fast growth of information technology, as well as the possibility of direct or indirect change within society. They also imply that multiple types of information and values are easily accessible, especially for students. Most institutions of higher education in major cities in Indonesia are equipped with internet hotspots or other means of internet access.

The internet, as well as French instruction books,

Table 1. Internet Use in Southeast Asia

\begin{tabular}{|c|c|c|c|c|}
\hline No & Country & $\mathbf{2 0 0 0}$ & $\mathbf{2 0 1 7}$ & Penetration \\
\hline 1 & Indonesia & $2,000,000$ & $132,700,000$ & $50.4 \%$ \\
\hline 2 & Philippines & $2,000,000$ & $54,000,000$ & $54 \%$ \\
\hline 3 & Vietnam & 200,000 & $49,741,762$ & $52.1 \%$ \\
\hline 4 & Thailand & $2,300,000$ & $41,000,000$ & $60 \%$ \\
\hline 5 & Malaysia & $3,700,000$ & $21,684,777$ & $69.6 \%$ \\
\hline 6 & Singapore & $1,200,000$ & $4,699,204$ & $81,2 \%$ \\
\hline 7 & Laos & 6,000 & $1,400,000$ & $19.9 \%$ \\
\hline 8 & Brunei & 3,000 & 310,205 & $71.4 \%$ \\
\hline
\end{tabular}

Source: Internet World Stats: www.internetworldstats.com/stats3.htm 
offer language learners diverse discourses as well as various voices and possibilities. For example, one discourse in a French instruction book used in Indonesian universities discusses the practice of religion in France. Although this theme is sensitive, it is a common subject of curiosity in an Indonesian context. It is known that Indonesia is the largest majority-Muslim country in the world, and questions of religion are embedded in the Indonesian identity; religion is also explicitly included on residents' national identity cards. The practice of religion is important in various aspects of Indonesian society, including in fashion. This is also represented in universities' French departments. In this research, informants responded enthusiastically to questions about religious practices in France and related them to their individual practices in Indonesia. During deep interviews with nine informants, of the 16 themes exposed in the instruction books (family, relationships, food, lifestyle, politics, tourism, media, fashion, architecture, leisure, city $\&$ village, education, environment, job, climate change, religious practice), religious practice in France received the longest and most intensive responses.

\section{Models of French-language learning in Indonesia}

In this section, we will further discuss the transmission of the French language and language practice, highlighting the different models of French language learning among Indonesian users in the context of higher education. One theme that is often discussed by language users

Figure 1. Student expelled from School for Wearing a Hijab in France

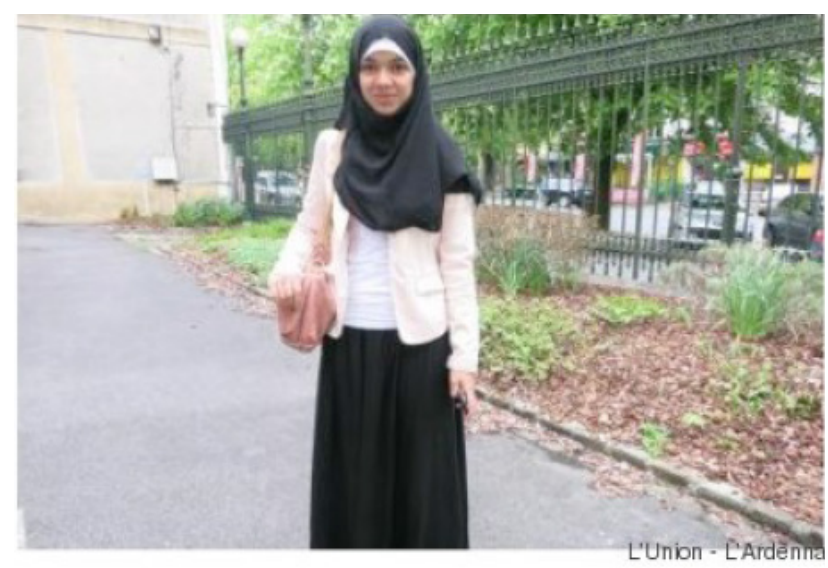

Source: http://www.huffingtonpost.fr/2015/04/28/ laicite-ecole-interdiction-cours-jupe-longue-jugee-signereligieux-ostentatoire_n_7164546.html during seminars, group discussions, and other formal and informal discourse practices is the practice of Islam in France. Analysing the French-language instruction books used, we found an article covering the prohibition of the use of Islamic veils (hijabs) at French schools. Informants' reactions to this topic differed depending on their attachment to the authoritative discourse of religious (Islamic) dogma.

Aside from exposure through language instruction books, French language users could also access such information through online media. The first prohibition of hijabs in French schools was passed in 1989, and since then the French media has reported many cases. One case, from 2015, is shown in Figure 1.

The existence of such a prohibition was met with protests by several students, and they perceived it as a form of discrimination, one that violated the French principle of equal access to education. To explain the rationale behind this prohibition, the French instruction book in question also presents an article introducing the French law on education and religious practice. Said law requires that all education, through the high school level, be compulsory, free, and laique (free of any religious symbols or practices). The concept of laicité, of French secularism, was new to all informants, and despite discussion in the classroom they still wondered why the French government was very strict regarding this issue.

Hijab-wearing is a common practice among Indonesian Muslim women, and some even consider it an obligation. However, it is sometimes not an indication of the level of one's religious practice, but a social and identity marker. Identity and ideology are often embedded in use and choice of clothing, and people in the public space are often categorised based on their clothes and style: students, parents, celebrities, priests, scientists, Muslims, tourists, etc. One will define and adapt their attitude and way of speaking according to the profile of their interlocutor. The first tool widely used to identify the profile of an unknown interlocutor is clothing, which as a visual element provides the first information and categories concerning people.

These categories indicate hegemonic sociocultural elements constructed through life experiences within families, schools, and societies. Therefore, in social practice clothing is a matter. Considering the $\mathrm{CEF}$ approach to language transmission, instructors must give an intercultural regard to this matter to ensure a better understanding among students. One instructor explained, as an illustration, that in Indonesia there is also a prohibition of certain clothes with ideological symbols. A recent case involved a French tourist who 
Figure 2. French Tourist Detained at Borobudur Temple for Wearing a T-Shirt with a Communist Symbol

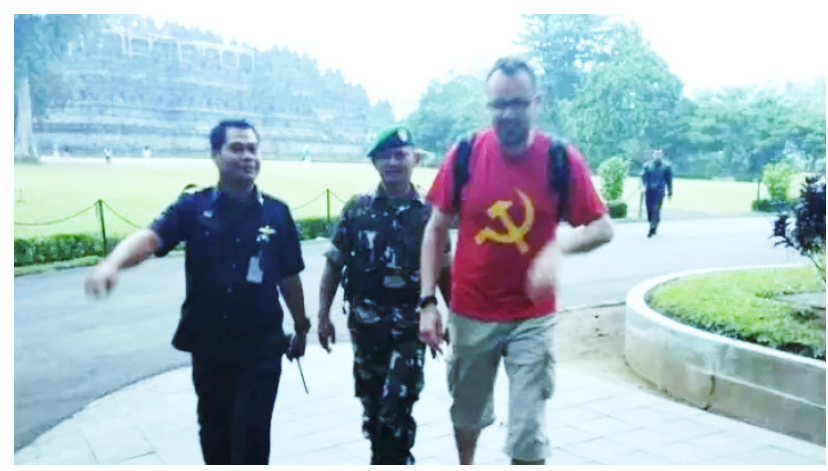

Source:http://citizen6.liputan6.com/read/3033723/alasan-bule-pakaikaus-pki-ke-borobudur-bikin-anggota-tni-luluh. Accessed 28 July 2017

was detained by security at Borobudur Temple. Until the guard explained that he was wearing one of the most strictly forbidden symbols in Indonesia, he had no clue that his choice of fashion - the hammer and sickle - could lead to his detainment (see Figure 2)

Considering the similarities in ideological struggle through fashion, language learners may have different perspectives when assimilating different discourses. As Bakhtin said, "our ideological development is just an intense struggle within us for hegemony among various available verbal and ideological points of view, approaches, directions and values" (Bakhtin, 1981, p. 346).

This research also analyses the social practices of informants as related to the different discourses and practices learnt. Three models of reproduction appear to be used by French-language users in Indonesian institutions of higher education. The first model is the total or complete adoption of French as an integral linguistic and sociocultural system. Some informants reached the point of changing their clothing and habits. One informant, Rina, is a 21-year-old student at the French department of a university. In one interview, she told us how she had changed after studying French:

"Setelah dua tahun belajar Prancis tuh, ini yang paling kelihatan berubah mbak, ini (Telunjuk diacungkan ke arah kepala). Dulu saya pakai jilbab, sekarang enggak. Godaan sih ini ya, godaan ya mbak, bener godaan. (Tertawa panjang)"

Translation: After two years of studying French, this is the most visible change (pointing at her head with both forefingers). I was wearing the hijab, but not anymore now. This is a sin, right? Yes, it is a sin (long laughter).

This interview showed that Rina experienced difficulty externalising her internally persuasive voice, her own voice. She acknowledged that, according to the authoritative voice of religious dogma, she has sinned. A hijab or veil is considered obligatory for women according to Islamic dogma. Not wearing the hijab, and letting others see their hair or most parts of the body, is seen as a sin for an adult woman. Rina understands this, and knows that the interviewer is also Muslim. Unconsciously, she used her lengthy laugh as a conversational strategy, which is known to ease awkwardness in an Indonesian context. During a later interview, Rina discussed in more detail how she felt about her change and decision.

Indeed, it would be naive and dangerous to conclude that the change experienced by Rina was caused only by her French language and culture acquisition at university. There are many aspects that could possibly influence her decision making. According to her narration during her interviews, three influences could be identified. First, there is her main environment, such as her close friends and her activities as a university student. Second, there are other knowledge input beside the university curriculum, such as reading and internet. The last aspect is related to the fact that she is staying alone in a boarding room in Yogyakarta, far from her parents and family. She has the freedom and independence to make her own decisions. According to Rina, her parents let her do whatever she likes as long as she takes all the responsibility. As she said during the interview:

"Orang tua aku terserah aku aja sih mba. Yang penting aku bisa tanggung jawab dengan semua yang aku kerjain. Mereka terserah aku aja."

Translation: My parents let me decide whatever I like. The important thing is that I am responsible for everything I do. They leave it up to me.

This last aspect shows that there is nearly no control over her youthful life, which is full of curiosity.

In the second model, French language users tend to select and adapt the discourses they learn. Their selection is basically made by maintaining authoritative discourse according to their existing ideology. One informant in this group is Sekar, a 22-year-old student who has completed her undergraduate degree and is now preparing for her master's studies in France. After learning French in an intensive programme for about a year, this is what she said: 
"Setelah belajar Prancis, rasanya biasa aja. Mungkin memang jadi lebih banyak tau tentang Prancis, tapi saya tetap perempuan jawa."

Translation: After studying French, it felt just normal. Maybe I know more about France now, but I am still a Javanese woman."

Sekar also wears a hijab in her everyday life, and in interviews she said that she would continue wearing it while studying in France. According to Sekar, her French studies gave her savoir and savoir-faire, but in practices of savoir-être concerning her identity she has chosen to be very selective and maintain her identity as a Javanese woman. Although in further discussions about this matter she was unable to provide her own comprehensive definition of being a Javanese woman, she knew in what cultural aspects she would accept the French way and in which aspects she would maintain the Javanese style, without confrontation and while always being polite. For example, when greeting a friend of the opposite sex, it is common for French people to kiss each other on both cheeks, sometimes three or four times, depending on their region of origin. On one hand, as a woman and Muslim, Sekar's authoritative voice rejects physical contact between persons of the opposite sex (except for family members). On the other hand, she understands the French sociocultural code. In negotiating between these two voices, she has compromised or adapted, deciding to explain her behaviour to her French friends. Sekar said that she has never had a problem with her choice.

Rina and Sekar live in different familial contexts. Both come from upper-middle class families from cities in Java. Sekar still lives with her parents and family, and thus in her discursive practices intertextuality (Fairclough, 1995) with her parents' voices is common (as their voices are considered authoritative voices that should be obeyed). Conversely, Rina lives more than 500 kilometres away from her parents, renting a room near her university. Despite her independence, Rina still receives a monthly allowance from her parents, who also cover her tuition fees. However, her parents' financial support does not influence her daily decision making and social practices. Most of the time, when speaking, she tended to express herself in her own way. She shared the imagined identity of emergent adults that is widespread on the internet and social media, which focuses mostly on individual freedom. She hardly recognised the cause of her change in the appearance, since "western" and "freedom" ideologies had long been transmitted through many channels of globalisation.

The third model is used by French-language users who only reproduce linguistic practices to complete academic tasks and meet administrative requirements. They perfectly understand most discourses presented in their French instruction books, but whenever they find elements that do not fit their ideology or socio-cultural values, they tend to ignore them. One informant in this category is Anwar, a 20-year-old student from a French department who is identified as a passive student with poor academic performance. After an interview with him, we were quite surprised to see his competence in speaking French, which belied his academic record. He told us that he often feels disturbed when completing tasks in class because he has difficulty understanding and accepting illustrations and images of French life and discourses. For him, most such illustrations incite wild ideas.

Once, his classmates complained because he refused to cooperate on a presentation about French fashion. His refusal was based on his feeling very disturbed by the female model in the fashion magazine they were supposed to analyse. Even then, in class Anwar never expresses his internal persuasive voice, nor the authoritative discourse that leads to his refusal. His silence and abstinence from various tasks or discursive practices can be considered his way of negotiating between French and Javanese ideology.

These three different models in the transmission of French as a foreign language shows the dynamics of identity construction among young adults as language learners and users. However, they have several common points in regards to age, gender, and religious identity. All informants live in the same era of globalisation, with borderless states and broadly shared voices and meanings. The identity transformations experienced by language learners should not be feared. As said by Bakhtin (1981, p. 346), "The semantic structure of an internally persuasive discourse is not finite. It is open; in each of the new contexts that dialogize it, this discourse is able to reveal ever newer ways to mean." In this perspective, the identity constructed by ideological choices is a mutable aspect, rather than a fixed or stagnant one. This is a subject for their discursive and social practices.

\section{CONCLUSION}

Through this article, we have examined the theoretical background to the politics of linguistics in Indonesia, with a focus on French. Also, we have analysed the practice of French language transmission in educational institutions, especially at the university level, which imply a more significant amount of French studies compared to the high school level. French language studies in Indonesia has 
adopted the new paradigm developed in Europe, known as the Common European Framework, which suggests that language acquisition should be accompanied with sociocultural action and discourses that will provide the language learner with the linguistic knowledge and the sociocultural behaviour. We have seen the typical responses of students to the discourses presented in their French-language books, and how they struggle to face the process of ideological confrontation. At their age, students are in the middle of an identity construction process that can be traced visually through clothing.

The above analysis of the politics of French linguistics in Indonesia shows the practice of $\mathrm{CEF}$ as a new reference in linguistic and didactic practices. Using a post-structural perspective and critical methodology to map the problem in this case, we have identified three models for reproducing French language and culture in the context of Indonesian higher education: adoption, adaptation, and abstinence. The three possibilities vary to the student environment and family background. One of the main environments with significant influence today is the internet-Indonesia being the number one country in internet usage in the Southeast Asia region.

\section{ACKNOWLEDGEMENTS}

I would like to express my gratitude to my academic supervisor and co-supervisor for introducing me to the complex world of scientific research and writing. I would also like to thank all of my informants for being essential parts of this research journey.

\section{ENDNOTES}

1)There are an average of 11,000 students registered at the French Institutes in Jakarta, Bandung, Yogyakarta, and Surabaya, as well as Alliances Françaises in Bali, Balikpapan, Medan, and Semarang. Sources: www.ambafrance-id.com, www.ifi-id.com.

\section{REFERENCES}

Attali, Jacques (2014). La francophonie et la francophile. Moteurs de croissance durable. Report to François Hollande, President of the French Republic.

Bakhtin, Mikhail (1981). The dialogic imagination: Four essays by M. M. Bakhtin. Austin: University of Texas Press.

Baskoro, BR Suryo (2000). Perbandingan artikel bahasa Prancis dengan bahasa Indonesia. Humaniora XI.

Beacco, Jean-Claude (2016). Ecole et politique linguistiques. Pour une gestion de la diversité linguistique. Paris:
Didier.

Benwell, Bethan \& Stokoe, Elizabeth (2006). Discourse and identity. Edinburg: Edinburg University Press.

Bourdieu, Pierre (1982). Ce que parler veut dire. Paris: Fayard.

Cholsy, Hayatul (2005). Penanda jamak dalam bahasa Prancis dan bahasa Indonesia. Humaniora, 17(1), 78-88.

Cholsy, Hayatul (2014). The status of French loanwords in the Indonesian language. Humaniora, 26(3), 303-314.

H Cholsy, IDP Wijana, FX Nadar, W Udasmoro (2017). Kata serapan dan kosakata bahasa Prancis dalam ranah kuliner dan mode di Indonesia. Unpublished dissertation. Yogyakarta: Universitas Gadjah Mada.

Cooper, Robert L. (1989). Language planning and social change. Cambridge: Cambridge University Press.

Dorléans, Bernard (2006). Orang Indonesia dan orang Prancis: Dari abad XVI sampai dengan abad XX. Jakarta: Gramedia.

Fairclough, Norman (1995). Critical discourse analysis: The critical study of language. New York: Longman.

Hall, Stuart (1996). Who needs 'identity'? In Hall Stuart, Du Gay Paul (eds.). Questions of cultural identity. London: Sage.

Norton, Bonny (2013). Identity and language learning: Extending the conversation. Toronto: Multilingual Matters.

Noworini, Sri Ekodoso (2003). Interferensi fonologi bahasa Indonesia dalam bahasa Prancis. Unpublished thesis. Yogyakarta: Faculty of Cultural Sciences, UGM.

Pavlenko, A. \& Norton, Bonny (2007). Imagined communities, identity, and English language teaching. In J. Cummins and C. Davison (eds.), International handbook of English language teaching. New York: Springer

Spolsky, Bernard \& Shohamy, Elana (2000). Language practice, language ideology, and language policy. In Spolsky Bernard and Shohamy Elana (eds.) Language policy and pedagogy. Amsterdam: John Benjamin Publishing.

Tobing, Roswita Lumban (2012). Tipe verba bahasa Prancis dan perwujudannya pada klausa. Jurnal Litera XI(1).

Tobing, Roswita Lumban (2012). Interferensi gramatika bahasa Indonesia ke dalam bahasa Prancis oleh pembelajar berbahasa Indonesia. Unpublished dissertation. Yogyakarta: Faculty of Cultural Sciences, Universitas Gadjah Mada.

Wright, Sue (2016). Language policy and language planning: From nationalism to globalisation. London: Palgrave Macmillan. 